\title{
SASKATCHEWAN DEPARTMENT OF THE ENVIRONMENT
}

Governing bodies, recognizing that there is an environmental crisis, are beginning to show in concrete ways that they intend to do what they can to monitor the amount of pollution, and possibly even do something to delay or even reverse the trend to deterioration. On this page in the June Blue Jay I commented on the Stockholm Conference, the first United Nations conference on environmental problems. Time will tell whether or not that conference was a success.

In Saskatchewan, on May 12 of this year, our government created a Department of the Environment in recognition of "legitimate" public concern about preservation of the environment in which we all live and work. As a fitting first activity the Minister and the Deputy Minister of the Department went to Stockholm and returned to our province after the conference aware of the difficulties of their respective assignments and resolved to do their best to prevent further deterioration of the human environment.

On August 2 your editor was kindly granted an interview with Mr. Neil E. Byers, Minister of the new Department of the Environment. Mr. Byers seemed interested in our society, and at the end of the meeting we both expressed the hope that this was but the first of many mutually profitable meetings which may take place between representatives of our respective groups.

The Department of the Environment as presently set up has three subdivisions. One is the Environmental Protection Service, which is subdivided again into an air pollution control branch, water pollution control branch, and the land protection service. The second is the Policy, Planning and Research Branch. The third is the Water Management Service.

The Minister explained that his department will set standards and that it will then be the responsibility of various other departments of the government to see that their activities do not result in levels of pollution greater than the maximum. This interrelationship between departments has resulted in the setting up of an Interagency Co-ordinating Committee which will review environmental management policies and develop guidelines for field administration of environmental control regulations. There will also be a 12 -member Environmental Advisory Council whose members are representatives of major interest groups. Because SNHS may be represented on this council, we should surely hear more of the activities of this group. The Minister said that his department is anxious to have public hearings and seminars and that it will welcome public participation in decision-making in environmental matters. The formation of an active public information and educational service within the department encourages me to think that the government is prepared to give some leadership in the recognition and correction of environmental problems.

I do not mean to imply from this that we can now relax and leave the health of Saskatchewan environments to the Government. The Department was formed only because of public demand and it will do a good job only if the public remains concerned. However, we now can send letters and resolutions to the Department of the Environment and expect that the personnel of the Department will read our submissions with sympathy and understanding. If, for example, you have a problem which relates to environment and natural resources, you should write to the appropriate person in the Department of Natural Resources and at the same time send copies to the Department of the Environment and to SNHIS. We anticipate that every worthy letter will get action.

It is obvious that each of us must accept more responsibility now that there are increasing indications that environment is becoming overwhelmed by man. We must become better informed; we must try to understand the diversity and the interrelationships which make for a fairly stable and healthy environment. When we see wrongs done against nature, we must report those wrongs, and we must do our best to see that the wrong doer repairs the damage or is punished. We hope that the new Department of the Environment will merit the approval of all those who are committed to preserving what remains of the natural environment of the province. 